\title{
Who Gets a Voice at the Table?: Eating and Blessing with Rav Naḥman
}

\author{
Marjorie Lehman
}

With gratitude I dedicate this analysis of Berakhot 51a-b to my teacher, RabbiJoel Roth, who understands the need for women to be counted as rabbinic leaders and as scholars in the field of Talmud and Rabbinics. Because of him, women have an equal voice at JTs.

For the rabbis, study and learning was a communal phenomenon, not an isolated experience. The third-century rabbinic scholar from the Land of Israel, R. Yose b. Hanina discredits learning alone, equating those who fail to study in partnership as enemies of the rabbinic elite and its overarching project. Solitude functions like a sword, maiming those who study unaccompanied, he claims. Ideal study involves two who "sharpen" the minds of one another (b. Ta'an. 7a). This image recalls the intense and passionate study relationship of R. Yohanan and Reish Lakish, as R. Yohanan says; "When[ever] I would say something, he [Reish Lakish] would pose 24 difficulties, and I would give 24 solutions, and as a result the subject became clear (b. B. Meș. 84b)."1 In building a male-male "fraternity" with Torah as its central value, ${ }^{2}$ the rabbis offer numerous examples of male rabbi-rabbi interchanges, featuring many of the characteristics of strong relationships - introspective dialogues, passionate discussions, rabbis willing to travel long distances to see one another, rabbis

1 The Beit Midrash (the House of Study) was the communal space where ideally these malemale (only) relationships were constructed and sustained. While there are numerous sources in rabbinic literature that refer to Batei Midrash (Houses of Study), scholars still have questions about their structure and scope. Catherine Hezser and Jeffrey Rubenstein argue that disciples gathered around a rabbinic master and learned traditions from him in his home or possibly in a private dwelling. See Catherine Hezser, The Social Structure of the Rabbinic Movement in Roman Palestine (Tübingen: Mohr Siebeck, 1997), 196-205; and Jeffrey Rubenstein, "Social and Institutional Settings of Rabbinic Literature," in The Cambridge Companion to Talmud and Rabbinic Literature, ed. Charlotte Elisheva Fonrobert and Martin S. Jaffee (Cambridge: Cambridge University Press, 2007), 59-6o.

2 Daniel Boyarin, Unheroic Conduct: The Rise of Heterosexuality and the Invention of the Jewish Man (Berkeley: University of California Press, 1997), 154. 
who dine together, not to mention relationships of respect and love. In fact, a rabbi's study partner is referred to as his haver (his friend). ${ }^{3}$ That said, in thinking about male rabbi-rabbi relationships it is important to recognize that the rabbis never shy away from exposing the downside of collegiality, including male competition, its power dynamics, the tensions between masters and their disciples, the struggles for authority, the desire to best the other at their own process of intellection, and most especially, the decision to be exclusivist in order to define the boundaries of their circle of companions. Such boundaries were constructed to close off entry to those who were not male, not rabbis, not Torah-knowledgeable, not heteronormative, not able-bodied, and not Jewish, thereby imposing social, religious, ideological and even physical exclusions on those with whom the rabbis lived their everyday lives.

For centuries many faced impenetrable boundaries and relied on rabbinic texts to support desired power structures. Indeed, a text, in and of itself, is not necessarily exclusionary unless someone grants it the power to be so. Feminist inquiry, in particular, pushes us to approach rabbinic texts from another vantage point, prompting a search for instances where the rabbis contest the very structures they construct. ${ }^{4}$ Indeed, the rabbis leave a record of their opposi-

3 See Mishnah Pirkei 'Avot 1:6 which states: "acquire for yourself a friend (haver)" and has traditionally been interpreted as stressing the need to find a study partner. The term, haver, however is also a technical term in Tannaitic literature, referring to a member of an elite group that is committed to maintaining strict standards of purity. In Sifre Deut. 305 (Finkelstein, Sifre on Deuteronomy, 323-324) and 'Avot Derabi Natan A 8:36 and B 18:40 to "acquire a friend" is defined as someone one eats with, drinks with, studies Scripture with, studies Oral Torah with, sleeps with, and to whom one reveals all his secrets of Torah and secrets of derekh 'eretz. In later rabbinic sources, it also connotes establishing friendship with someone who maintains piety, righteousness, purity, not to mention, one who studies Torah. See Jonathan Wyn Schofer, The Making of a Sage: A Study in Rabbinic Ethics (Madison: University of Wisconsin Press, 2005), 33. See also Catherine Hezser, "Rabbis and Other Friends," in The Talmud Yerushalmi and Graeco-Roman Culture, ed. P. Schäfer and C. Hezser (Tübingen: Mohr Siebeck, 200o), 2:189-254, esp. 202.

4 See Charlotte Fonrobert, "Feminist Interpretation of Rabbinic Literature: Two Views," Nashim: A Journal of Jewish Women's Studies and Gender Issues 4 (2001): 10. Following in the path of Fonrobert, I root myself in Daniel Boyarin's (now twenty-five-year old) approach exhorting us to pay attention to the ruptures and the discontinuities that highlight cracks in the rabbis' systems of power, ones that emerge when we pay attention to the very sources that comprise a rabbinic sugya (119). See Daniel Boyarin, "Rabbinic Resistance to Male Domination: A Case Study in Talmudic Cultural Poetics," in Interpreting Judaism in a Postmodern Age, ed. Steven Kepnes (New York: New York University Press), 119; Carnal Israel (Berkeley: University of California Press, 1993), 227-228; "Reading Androcentrism against the Grain: Women, Sex, and Torah-Study," Poetics Today 12, no. 1 (1991): 29-3o. Also see Jana Sawicki, Disciplining Foucault: Feminism, Power, and the Body (Thinking Gender) (New York: Routledge, 1991), 14. 
tion to the values they purport, that is, "a fissure" for us to creep into, if only we look for it. ${ }^{5}$ Significantly, we find that just as there are rabbinic sources about collegiality, passionate dialogues, students searching out teachers and teachers learning from students all in the name of Torah, there is also a thread that exposes the rabbis' vulnerability as well as the pain and the loss that comes with asserting an authority wedded not only to what one knows, and who one knows, but also to the ways one acquires knowledge. ${ }^{6}$ Inasmuch as the rabbis go to great lengths while in conversation with other rabbis to establish their authority as legal experts, they also challenge the ways that authority is affirmed, highlighting problems that exist on the inside of power, that is, within their rabbi-rabbi sphere. At the same time, they also assert how that sphere affects others outside of it.

While rooted in a feminist methodology, the focus of this analysis is sociological, that is, on how relationships were defined and constrained by the social structures, including the learning aspirations, in place at the time. ${ }^{7}$ The emphasis will be on the structure of rabbinic society and how its weddedness not only to the acquisition of Torah knowledge, but also to halakhah and ritual observance, controlled interpersonal connections and choices. A shared value system as well as shared norms link the individuals who claim membership. Not surprisingly, rabbinic Jews are socialized into particular gender and power relationships that govern who leads and who is led, that is, who teaches and who is taught. ${ }^{8}$ But, they also recognize what is at stake in a system that connects Torah knowledge with interpersonal relationships as well as with status, authority, power and control. ${ }^{9}$ As such, the rabbis reflect and critique the

5 Boyarin, "Rabbinic Resistance to Male Domination," 125-126.

6 See Schofer, The Making of a Sage, where he argues that the rabbis' "elitism and sexism are entangled with their persuasive visions of community and fellowship," 22.

7 Graham Allan, Friendship: Developing a Sociological Perspective (Boulder: Westview Press, 1989), 2, 8-9.

8 Elite Ben-Yosef, "Literacy and Power: The Shiyour as a Site of Subordination and Empowerment for Chabad Women," Journal of Feminist Studies in Religion 27, no. 1 (2011): 58.

9 Present-day research is prevalent regarding the value of cooperative learning and teaching that centers, more specifically, on havruta study with respect to Talmud. See Jeff Kress and Marjorie Lehman, "The Babylonian Talmud in Cognitive Perspective: Reflections on the Nature of the Bavli and Its Pedagogical Implications," Journal of Jewish Education 69, no. 2 (2003): 58-78; Elie Holzer and Orit Kent, A Philosophy of Havruta: Understanding and Teaching the Art of Text Study in Pairs (Boston: Academic Studies Press, 2014); and Elie Holzer, Attuned Learning: Rabbinic Texts on Habits of the Heart in Learning Interactions (Boston: Academic Studies Press, 2016). Additionally, in the field of general education, many have turned to the cognitive development psychologist, Lev Vygotsky, who emphasizes the significance of the social nature of learning, suggesting that students be engaged together in learning activ- 
patriarchal framework that they so desire to construct. Their self-critique repositions us to think about the effects of power in our own relationships, whether they involve teaching and learning, or not. ${ }^{10}$

Rabbinic literature offers us many rabbi-rabbi interchanges, not to mention numerous stories of rabbis engaging with non-rabbis. For this reason, there are many entry points for examining the sociological framework that conditions the rabbis' interpersonal relationships. Rather than centering this analysis on the rabbinic term for a rabbi-study partner, haver, or on one rabbinic corpus, or on tracing a given rabbi-rabbi relationship throughout Talmudic literature, or on examining the way rabbis learn from and with one another, I have chosen to focus on one aggadic story found in Massekhet (tractate) Berakhot of the Babylonian Talmud as a paradigm for continued work on examining the social-emotional elements that connected one individual with another or, in some cases, drove them apart. ${ }^{11}$ Rooted within the seventh chapter of tractate Berakhot with its focus on Birkat Hamazon (Grace after Meals) recited in a rabbi's home rather than in the Beit Midrash, the purpose is to think about the ways the rabbis present the interpersonal interactions taking place around a commonplace event mentioned frequently in rabbinic texts, of people eating together. ${ }^{12}$ Within the context of discussing the laws and etiquette of reciting Birkat Hamazon together with others, there is a story that appears only in the Bavli (Ber. $51 \mathrm{~b}$ ). The story involves two rabbis and one woman and invites analysis regarding the relationship among them. It is just one example, among many,

ities to achieve the greatest outcomes. Vygotsky argued that the cognitive development of an individual cannot be understood outside the patterns of relationships and interactions in which such development takes place. Samuel J. Hausfather, "Vygotsky and Schooling: Creating a Social Context for Learning," Action in Teacher Education 18 (1996): 1-4; James A. Wertsch, Vygotsky and the Social Formation of the Mind (Cambridge: Harvard University Press, 1985), 59-76.

10 In some instances, scholars have used Talmudic material as case studies in the service of teacher development for today's Jewish educators, exploring master-disciple interactions; see Jane Kanarek and Marjorie Lehman, "Making a Case for Rabbinic Pedagogy," in The International Handbook of Jewish Education, ed. L. Grant and A. Pomson (New York: Springer, 2011), 581-596; and see Moshe Berger, "Towards the Development of Jewish Pedagogy: Rav Hiya's Vision of Torah Education," in Judaism and Education: Essays in Honor of Walter I. Ackerman, ed. Haim Marantz (Beer-sheva: Ben Gurion University of the Negev Press, 1998), 109-120; and the collection of essays in Turn It and Turn It Again: Studies in the Teaching and Learning of Classical Jewish Texts, ed. J.A. Levisohn and S.P. Fendrick (Brighton: Academic Studies Press, 2013).

11 See Schofer, The Making of a Sage, 4.

12 See Hezser, "Rabbis and Friends," 216-221. Although Hezser focuses primarily on sources found in the Jerusalem Talmud, she also contextualizes eating habits in Greco-Roman sources in an attempt to describe the realia of the time. 
of how ritual practice, authority, gender, and knowledge as well as the emotions of respect, frustration, anger, and jealousy intersect to build and undermine relationships in rabbinic culture, ultimately with lessons for us today.

Unsurprisingly, the male-male homosocial structure of rabbinic culture generated many instances of male rabbis dining together, presumably discussing Torah as an extension of their learning partnerships in the Beit Midrash..$^{13}$ These discussions about meals prevalent in the Talmuds, from the Passover seder to the daily meal, most especially in the seventh chapter of Massekhet Berakhot, suggest that rabbis dined with or around non-rabbis. At each meal space one might find servers, Cutim, non-Jews, women, children, slaves, and 'amei ha'aretz ${ }^{14}$ in close proximity to the rabbinic elite. ${ }^{15}$ While some of these individuals could join the introductory invitation to Birkat Hamazon, called zimun, to complete the cohort of three necessary for invoking this initial call to blessing, including a server, a non-Jew and a Cuti; others, including women, minors, and slaves could not join together. ${ }^{16}$ Therefore, looking at the structure of meal rituals, with blessings before meals and blessings afterward to sanctify God, offers a window into who had an actual "seat at the table." Who counted as the hosts' companions? And, what was the nature of that companionship? No doubt, a lot of ambiguity emerges in trying to determine whether women, when present at meals, are related to the host, or what the nature of the relationship was among rabbis dining together, especially when one rabbi was from the Land of Israel and one from Babylonia. Because we can never really know how people mentioned together in rabbinic sources came to know

13 Regarding the fact that women also gathered together to perform rituals in havurot, see Judith Hauptman, "From the Kitchen to the Dining Room: Women and Ritual Activities in Tractate Pesahim," in A Feminist Commentary on the Babylonian Talmud: Introduction and Studies, ed. T. Ilan et al. (Tübingen: Mohr Siebeck, 2007), 122-124. See also b. Ber. $45 \mathrm{~b}$ regarding the allowance for women to make their own zimun. Also see Charlotte Fonrobert's larger discussion, "Gender Politics in the Rabbinic Neighborhood: Tractate Eruvin," in A Feminist Commentary on the Babylonian Talmud: Introduction and Studies, ed. T. Ilan et al. (Tübingen: Mohr Siebeck, 2007), 51.

14 See for example, b. Ber. 47 b where an 'am ha'aretz is not included in zimun. An 'am ha'aretz can generally refer to someone who is not Torah-knowledgeable, although here the baraitan (Tannaitic) material is more specific in defining an 'am ha'aretz more broadly to include anyone who does not know the laws of tithing to someone who reads Torah and Mishnah, but not Gemara. Also see b. Sotah 22a.

15 See m. Ber. 7:1; b. Ber. 46b (dining together with less prominent people); $47 \mathrm{~b}$ (with servers, cutim); $47 \mathrm{~b}$ (with 'amei ha'aretz); $47 \mathrm{~b}$ (with sons who are not Torah-knowledgeable); $47 \mathrm{~b}$ (with those who have not tithed); $47 \mathrm{~b}$ (with women, slaves and minors); and $47 \mathrm{~b}$ (with Canaanite slaves).

16 Women were allowed to join together and perform zimun. However, women could not join with other men. They also could not join together with slaves or minors. See b. Ber. $45 \mathrm{~b}$. 
one another, all that we can unearth are observations about the patterns of social integration among those who belong to a similar communal organizational structure, one that, indeed, shaped their ties to one another. ${ }^{17}$

\section{Birkat Hamazon and the Ritual of the Cup of Blessing}

Rabbinic literature discusses many holy moments that revolve around a cup of wine. Wine marks sanctified time. Weddings, circumcisions, holiday Kiddush, Shabbat Kiddush, and Havdalah are all accompanied by wine (b. Pesah. 105b-106a). According to tractate Berakhot, one also said Birkat Hamazon with a cup of wine, referred to as a "cup of blessing" (kos shel berakhah) in b. Ber. $51 \mathrm{ab} .{ }^{18}$ The cup was passed to those who ate together, although it is not clear whether someone eating alone would also use a cup of wine when reciting Birkat Hamazon. ${ }^{19}$ On one level, the ritual seems somewhat odd. Why does the four-paragraph long recitation of Birkat Hamazon to thank God for one's food in fulfillment of the Toraitic commandment (Deut 8:10) require a cup of wine? Does this wine rite convey a desire to extend more gratitude to God? Is it for the purposes of sanctification? Or maybe it is about praising God still further? Ber. 51a leaves us with the impression that the purpose of reciting Birkat Hamazon along with a "cup of blessing" is to request God's blessing for physical land and/or spiritual space, building on the theme developed in the second blessing of Birkat Hamazon:

R. Yohanan said: Whoever recites Birkat Hamazon over a full cup is awarded an inheritance beyond boundaries, as it is said [by Moses before his death, "O Naftali, sated with favor, and full of the Lord's blessing, you will], take possession on the west and south" (Deut 33:23). R. Yose b. Hanina says: He merits and inherits two worlds, this world and the world to come. ${ }^{20}$

However, while not to confuse the recitation of Birkat Hamazon with zimun or zimun with the appearance of this additional ritual component, the "cup of blessing," the following story suggests that it was customary in Babylonia to

\footnotetext{
17 Allan, Friendship, 18.

18 Also see b. Ber. 48a regarding King Yannai and R. Sheshet as well as the discussion below.

19 See Shulhan Arukh, оH 182 indicating that as late as the early 16 th century this issue was still the subject of halakhic debate. 
pass a cup of wine to those partaking of a meal together. Seen this way, the cup of blessing communicates that people eating together construct a moment of holiness by virtue of being with one another. The group created sanctifies this moment in time. Additionally, not only was it customary for guests who led Birkat Hamazon to bless their hosts (b. Ber. 46a), in passing the cup of blessing to each person, they expressed a desire that God would continue to bestow blessing on those with whom they dined, paralleling God's blessing of food. Therefore, the ritual of passing the cup of blessing to those around one's table works in tandem with acknowledging the value of interpersonal relationships.

Ber. $51 \mathrm{~b}$ in the Babylonian Talmud includes a story about a meal that occurred at the home of the prominent Amoraic rabbi from Babylonia, Rav Nahman bar Ya'akov (d. 320). Ulla, an equally eminent rabbi from the Land of Israel and of the same generation, is dining with him. ${ }^{21}$ One of the few named women in the Bavli, Yalta, is present as well. Ulla signifies the power of the Jewish community in the Land of Israel as a rabbinic center and its desire to assert control over Babylonia. Known as an itinerant rabbi, he has come to Babylonia to do just that. ${ }^{22} \mathrm{R}$. Nahman stands for the authority of the Babylonian rabbinate while Yalta represents the non-rabbi, the rabbinic "other." Possibly she is R. Nahman's wife or a member of his household. We cannot be sure. ${ }^{23}$ But, at the very least, the appearance of a woman along with Ulla and Rav Nahman is far from incidental. ${ }^{24}$ Her inclusion problematizes the ways that relationships are cultivated among male rabbis so as to reveal the underside of rabbinic

21 Both R. Nahman and Ulla were third-generation Amoraim.

22 For more examples of Ulla's travels from the Land of Israel to Babylonia see b. Šabb. 157b (where Ulla visits the Babylonian exilarch); and b. Ned. 22a (where Ulla returns to the Land of Israel).

23 See Tal Ilan's discussion of Yalta in Mine and Yours Are Hers: Retrieving Women's History from Rabbinic Literature (Leiden: Brill, 1997), 122 and n. 61. Also see Ilan's final comment about Yalta where she claims that the proximity between men and women in rabbinic literature, like R. Nahman and Yalta, led many to presume that they were married when this might not have been the case (129). She also points out that Talmudic sources refer to Homa as Abaye's wife (b. Ketub. 65a), Beruriah as R. Meir's wife (b. Ber. 1oa; b. Pesah. 62b; and b. 'Abod. Zar. 18a) and Imma Shalom as R. Eliezer's wife (b. Šabb. 116a and b. B. Meș. $59 \mathrm{~b})$. While it is true that in five of the seven instances in the Bavli that mention Yalta, R. Nahman appears as well, each of these instances leaves a degree of ambiguity as to how she is related to him and do not mention that she is his wife. b. Ber. 51ab mentions the word for wife, ביתהו, but does not do so immediately following Yalta's name in a way that would mark her clearly as the wife of R. Naḥman. Indeed, her relationship to R. Nahman is ambiguous.

24 See Michael Satlow, "Fictional Women: A Study in Stereotypes," in The Talmud Yerushalmi and Greco-Roman Culture, ed., P. Schafer (Tübingen: Mohr Siebeck, 2002), 3:226, 233; and Fonrobert, "Gender Politics in the Rabbinic Neighborhood," 51. 
patriarchal authority, that is, the way that it can cultivate a desire for one to outdo another with their Torah knowledge. ${ }^{25}$ Instead of constructing social relations and reinforcing stable rabbinic cultural norms, as many narratives do in rabbinic literature, this story questions what the rabbis construct-does it always work? Indeed, what we find percolating beneath the interactions between the figures in this rabbinic story is a failed sense of the rabbi-rabbi relationship, not to mention a strained connection with others who are not rabbis. The story exposes the precarious grounds upon which the rabbis fashion their authority, even within a social group that held Torah and halakhah as central. The story begins as follows:

[And the following incident occurred]: Ulla visited the house of R. Nahman.

He [Ulla] ate bread and recited Birkat Hamazon. He [then] passed the cup of blessing to R. Nahman. R. Nahman said to him [Ulla], "Let Master send the cup of blessing to Yalta."

Amid the daily ritual of Birkat Hamazon, R. Nahman requests that Ulla pass the "cup of blessing" to Yalta, in keeping with what appears to be a Babylonian custom of sharing the cup with the members of one's household, including one's wife. Ulla seems to have a different custom where the "cup of blessing" is only passed to the men at the table. To assert his rabbinic prowess, that is, to prove his deep knowledge of Torah and of course to support his point, Ulla not only refers to a verse from Deuteronomy, but also quotes the opinion of the second-generation Amora from the land of Israel, R. Yohanan (d. 290), a rabbinic colleague from the generation prior to his own. In addition, the redactor of the story includes the opinion of the Tanna, R. Natan, who is also from the Land of Israel. The presence of R. Natan's opinion bolsters the authority of R. Yohanan's argument, pointing to its origins in the Tannaitic era:

[Ulla said to R. Nahmman, that is not necessary] because R. Yohanan said: "The fruit of a woman's belly [womb] is only blessed through the fruit of a man's belly, as it is written [in Deut 7:13], 'He [God] will bless the fruit of your [male (heb. singular)] belly.' It does not say the fruit of her belly but [rather it says] the fruit of your [masculine] belly."

It was similarly taught in a baraita: R. Natan said: "From where [do we derive from Scripture] that the fruits of a woman's belly are only blessed 
through the fruits of the husband's belly? For it is stated: 'And He [God] will bless the fruits of your [masculine] belly'; it does not say, the fruits of her belly."26

Unquestionably, Ulla's decision not to pass the cup of blessing to Yalta is an insult to her as well as to his host. He wants to flex his masculine rabbinic muscle by claiming that his decision emerges from an interpretation of a verse in Deuteronomy - mentioning blessing. In so doing, he deems men as having sole procreative power. Claiming that the blessing of progeny comes only from male seed ("his belly"), rather than from the womb of women, he renders Yalta (and all women) completely irrelevant, not to mention undeserving of blessing. ${ }^{27}$ Objectified, she has no voice, despite material elsewhere in the Bavli suggesting that she too is Torah-knowledgeable. ${ }^{28}$

Ulla seems to care more about being right, more about imposing his own custom on R. Nahmman, and more about asserting hegemony over his Babylonian colleague. In this regard, teaching Torah is not a neutral act. It emerges from a desire to dominate another rabbi, solidifying his own power as if to represent that of the rabbis in the Land of Israel. ${ }^{29}$ Ulla's knowledge of Torah and his familiarity with the teachings of his predecessors overrides the respect due to those at whose table he sits. Furthermore, any potential openness to another way of performing the "cup of blessing" rite is squelched by the commitment to, and knowledge of, a chain of legal transmission in the names of R. Natan and R. Yohanan. Ulla's knowledge is the knowledge of a past rabbinic scholar and repeating it gives him great authority. Ironically, the performance of this rite (whether it includes zimun, the four-paragraph long Birkat Hamazon, or the additional "cup of blessing" that has as its objective-blessing God and the

26 Deut 7:13 (larger context):

And if you obey these rules: God will favor and bless you and multiply you. He will bless the issue of your womb and the produce of your soil, your new grain and wine and oil, the calving of your herd and the lambing of your flock, in the land that he swore to your fathers-you shall be blessed above all other peoples—-there shall be no sterile male

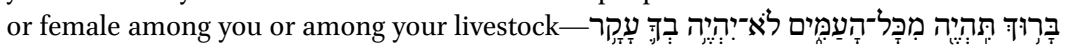

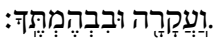

27 See b. Nid. 31 b where the physiological differences between men and women are discussed in greater detail. Discussing ways that the male body differs from the female body can be found in many places in rabbinic literature.

28 See b. Hul. 1ogb and b. Nid. 2ob. Also see Charlotte E. Fonrobert, Menstrual Purity: Rabbinic and Christian Reconstructions of Biblical Gender (Stanford: Stanford University Press, 200o), 118-127; and Ilan, Mine and Yours Are Hers, 122 and 127.

29 Madeleine Arnot, "Male Hegemony, Social Class, and Women's Education," Journal of Education 164, no. 1 (1982): 64-89. 
others with whom one dines), reveals Ulla's self-centeredness in his attempt to isolate R. Nahman in his own home, as well as Yalta. Failing to pass the cup to Yalta, that is, disrespecting R. Nahman albeit through the lens of his knowledge of a midrashic support, highlights the complexities of membership in the rabbinic hierarchy - when what you know effects who you know and controls the way you engage in conversation.

Ulla's self-centeredness is not surprising given the rabbinic milieu into which he is born. Looking just at the etiquette surrounding the performance of Birkat Hamazon, as conveyed in the seventh chapter of tractate Berakhot, presents a glimpse into a world where, understandably, egos are built and shattered. The manner in which rabbis were to recite the zimun or Birkat Hamazon accentuated how much they were valued for their Torah scholarship. For example, in a narrative appearing earlier in this chapter and mentioning a "cup of blessing," the Jewish king Yannai, an enemy of the rabbis who-according to b. Qidd. 66a, had massacred them in his desire to consolidate power-discloses to his wife, the queen, that he could not recite Birkat Hamazon without a member of the rabbinic elite leading him. Therefore, he turns to Shimon b. Shetah, the brother of the queen and a lone rabbi-survivor, to recite it (b. Ber. 48a). ${ }^{30}$ The message: even kings need the rabbis to perform daily rituals in accordance with the rules that the rabbis invent, despite how much kings, such as Yannai, despise them. Additionally, halakhic sources in the very same chapter convey that reciting zimun, followed by Birkat Hamazon, falls to the person at the table with the greatest knowledge of Torah (b. Ber. 47a). ${ }^{31}$ And while it was also the custom that a guest led Birkat Hamazon in order to graciously bless his host (b. Ber. 46a), read contextually this text suggests that such a guest did so in accordance with his status as compared to others at the table. Additionally, two Torah scholars, each of whom had the ability to sharpen the intellect of the other in matters of halakhah, could join to form a zimun that, by law, required three individuals. This means that their (inanimate) Torah knowledge counted as the third person (b. Ber. $47 \mathrm{~b}$ ). Finally, rabbis who ate together and were of equal stature did not join in saying Birkat Hamazon, but recited it alone, to signify that each respected the knowledge of the other (b. Ber. 45b). Given how much the rabbis valued Torah knowledge and community, it seems counterintuitive to encourage colleagues of equal status to bless God individually, especially while they

30 See b. Qidd. 66a for the extensive narrative on King Yannai's destruction of the rabbis. See y. Ber. 7:2, $11 \mathrm{~b}$ for another version of this story.

31 See Rashi b. Ber. 45b, s.v. lo havu behu ("and there was none among them") where Rashi argues that greatness was measured in accordance with both knowledge of Torah and age. Also see b. B. Bat. 120a. 
happen to be together at the same table. Such etiquette seems to discourage the experience of rabbinic colleagues coming together at a meal, and subverts the overarching theme of the chapter, which is zimun and blessing God as a group. In fact, the larger the group, the greater the blessing. ${ }^{32}$ Admittedly, the rabbis use food ritual to instantiate a desired hierarchical social structure. And the way daily rituals are discussed here underscores how a rabbi's communal standing was structured around who knew the most Torah. Ulla's status is recognized when R. Nahman allows Ulla to recite Birkat Hamazon.

For men status was achieved most readily through Torah knowledge and Torah granted them communal status; for women it was all about marriage and procreation. Interestingly, in this story it is not clear that Yalta is married to R. Nahman, that she is pregnant, or has children. She also does not appear to be the housewife, the server, or the cook. ${ }^{33}$ The details are simply not clear. The ambiguity generates a feeling that she is here to confuse categories, rather than to offer a clear-cut rabbinic characterization of a rabbi's wife. ${ }^{34}$ She leaves open the possibility that some women did, in fact, converse with men because, at least as the story begins, she seems to have a seat at the table; R. Nahman wants the "cup of blessing" passed to her. ${ }^{35}$

32 See b. Ber. 49b-5oa, especially the mishnah (m. Ber. 7:3) where it indicates that three people who have eaten together are to say, "Let us bless," ten people who eat together add to their zimun saying, "Let us bless our God," 100 people who eat together continue to add to zimun and say, "Let us bless God, who is our God," etc ... However, the gemara that comments on this mishnah indicates a desire to use the same language for zimun whether there are ten or more than ten.

33 There are many rabbinic sources that refer to women taking part in domestic tasks, although here Yalta is not mentioned in conjunction which them. In fact, there are several Talmudic anecdotes, for example, that speak of women who bring food to the head of household. See, for example, y. Šabb. 3:1, 5d; b. Šabb. 48a; b. Šabb. 51a. See Judith Hauptman's discussion in "A New View of Women and Torah Study in the Talmudic Period," JSIJ 9 (2010): 263, esp. note 40, https://www.biu.ac.il/JS/JSIJ/9-2010/Hauptman.pdf; and her article, "Hadavar masur lenashim: nashim betekasei daat beitim," Sidra (5770): 83-111.

34 See Satlow, "Fictional Women," 228-230 for a good overview of rabbinic stereotypes of women, specifically regarding domesticity. Also see Dina Stein, "A Maidservant and Her Master's Voice: Discourse, Identity, and Eros in Rabbinic Texts," Journal of the History of Sexuality 10, nos. 3-4 (2001): 377, where she discusses how the relationship between Rabbi Yehudah the Patriarch and his maidservant blur the expected hierarchy of social categories. See also Hauptman's Talmudic examples in her article, "A New View of Women and Torah Study in the Talmudic Period," where women voice their knowledge of matters of halakhah, indicating that in certain areas they were Torah knowledgeable; JSIJ 9 (2010), https://www.biu.ac.il/JS/JSIJ/9-2010/Hauptman.pdf, 249-292.

35 Galit Hasan-Rokem, Tales of the Neighborhood:Jewish Narrative Dialogues in Late Antiquity (Berkeley: University of California Press, 2003), prompts discussion on whether Yalta could be a neighbor and not R. Naḥman's wife. Unfortunately, as she points out, even 
We also know from other sources, specifically b. Qidd. 7oab, that Yalta advised R. Nahman and offered halakhic advice to men in the areas of niddah and kashrut (b. Nid. 2ob and b. Hul. 1ogb). She also helped to heal R. Amram who was tortured by the "house of the exilarch," bathing him so that he would recover (b. Git. 67b). This suggests that the pattern of rabbinic relationships outside the Beit Midrash, that is, of men discussing Torah or eating together, may not always be gendered male. At the very least, given that the issue in b. Ber. $51 \mathrm{~b}$ revolves around a "cup of blessing," as compared to numerous examples in chapter 7 of tractate Berakhot that discuss zimun (from which Yalta would have been excluded at this meal), it seems that by including an interaction between two rabbis and a woman, a woman who may or may not be R. Nahmman's wife, there is a desire to test how far the exclusion of women should go. ${ }^{36}$ Who is in and who is out? Who controls the decision and under what circumstances?

As it happens, Ulla's teaching in the name of R. Yohananan, does not make sense; he seems to misread the verse. Not only does the context in Deuteronomy refer to blessing both men and women with progeny saying, "there shall be no sterile male or female among you (7:13)," but Deuteronomy also makes clear: women become pregnant and give birth to children and it is a blessing God bestows. The Talmud's redactors, possibly recognizing the weakness of R. Yohanan's interpretive comment, inform us that this teaching about male seed originated with the earlier Tannaitic rabbi, R. Natan, a Talmudic move that

though neighbors are the closest relationship in ancient culture beyond the family unit, the relationship is often overlooked. While in patriarchal cultures, neighbors may belong to the same family, aggadic stories in rabbinic literature that present dialogues between neighbors often include women as their protagonists who may not be family members. Due to their frequent presence at the homes of others, they can be considered members of the household (8 and 11). See also Hezser, "Rabbis and Other Friends," 216, who discusses neighbors in the ancient world, noting that friends who were neighbors crossed the threshold into another's home and became intimates of the family. If Yalta and R. Nahman are neighbors, this might introduce the potential for a relationship of symmetry and mutuality, more so than if she is his wife, serving him. Indeed, there are instances in rabbinic literature where women sought out rabbis to study with them, although, in the case of the wife who studied with R. Meir, she was berated by her husband and discouraged by her female neighbors from returning to study. See Vayikra Rabbah (Margoliot edition), 96:9; y. Sotah 1:4, 16d. Also see a summary of the sources referring to Beruriah in Marjorie Lehman, "Reading Beruriah through the Lens of Isaac Bashevis Singer's Yentl," Nashim: A Journal of Jewish Women's Studies and Gender Issues, 31, no. 1 (2017): 123-145.

36 See Fonrobert, "Gender Politics in the Rabbinic Neighborhood," 52-53, where she argues that the presence of women within a discussion about rituals (in her case, the 'eruv), serves a meta-halakhic purpose. Fonrobert reminds us of the importance of seeing the presence of women in rabbinic narratives as pointing to something the rabbis wish to express about themselves, their communal framework or about the laws they create. 
surely supports Ulla. Additionally, while Ulla transmits the view of others, he adds nothing creative to the discussion. He sees women as the receptacles of male seed, yet he is nothing more than a vessel containing rabbinic wisdom to which he adds nothing.

In addition, the presence of Yalta conveys a degree of anxiousness on the part of the rabbis about the nature of male authority. Ulla's legal reasoning is faulty, and his ethics are questionable. He does not use his Torah knowledge to show respect for R. Nahman or for Yalta by engaging them. He merely discredits their custom entirely, as if to say, "I am right and you are wrong." Ironically, Torah knowledge, which defines his relationship with R. Nahman, distances him from his host and from Yalta. In addition, he invokes the authority of his predecessor in the Land of Israel, R. Yohanan when R. Yohanan is not at the table. Why does Ulla's respect for R. Yohanan supersede his respect for those of his own generation who happen to be alongside him? Why does he venerate his predecessors, and disparage his contemporary, R. Nahman? Collegiality is missing; the opportunity for two rabbis to learn from one another is thwarted; connections between the Land of Israel and Babylonia are strained - all in the name of a desire to assert that, "what I know is better than what you know."

The response on the part of Yalta to Ulla is anger and frustration. She "rose passionately and went to the wine storehouse and broke 400 barrels of wine."37 Her method of communication feels stereotypically female in that she acts emotionally rather than engaging Ulla in a more typical male-male / rabbirabbi verbal debate. It is also symbolic. Don't dismiss the vessel, she communicates to Ulla, because without the vessel, there is no wine; that is, without a woman's womb, there is no child. And with this Yalta challenges the control Ulla presumes he has. Arguably, the relationship between men and women, as Ulla understands it, is one of total power of men over women, even in creating progeny. A woman is blessed through a man; she has children because of him. But what Yalta reveals when she smashes 400 barrels of wine is that men, in fact, depend on the object of their power wholeheartedly. ${ }^{38}$ Recognizably, they do need women. Ulla's midrashic words are empty, just like the barrels.

37 See also b. Ketub. 104a where the maidservant of Rabbi Yehudah Hanasi throws a jar off the roof to silence those praying for his mercy, competing with God who wanted him as well. Upon hearing the noise, the rabbis stop praying and R. Yehudah dies. See Stein "A Maidservant and Her Master's Voice," 391 and her discussion 392-393.

38 See Stein, “A Maidservant and Her Master's Voice," 377, who in quoting Hegel's understanding of the master-slave relationship argues that "total personal power becomes a form of total dependence on the object of that power"; see George Wilhelm Hegel, Phenomenology of the Mind, trans. J.B. Baillie (London: Sonnenschein, 1910), 228-240; and W. Fitzgerald, Slavery in the Literary Imagination (Cambridge: Cambridge University Press, 200o), 1-8. 
Although Yalta's message comes through to R. Nahman, he seems to back down in support of Ulla. When he says, "Let the Master send her another cup," R. Nahman appears to favor Yalta, but instead he fuels the fire. "Another cup," , כסא אחרינא, would not be the one over which Birkat Hamazon was already said; it would be an entirely new cup. It would be a cup of wine with no connection to the ritual that was just performed. There is no plan to repeat Birkat Hamazon. In so doing, R. Nahman offers a compromise position, kowtowing to Ulla, but trying to pacify Yalta at the same time. Such a make-up strategy merely reinvokes the rabbinic social status quo where men assert their power over women and the hierarchy is maintained. ${ }^{39}$ Passing a second cup to Yalta signifies that she is, in fact, second to R. Nahman and Ulla. She is pushed to the sidelines, positioned exactly where, in this socio-cultural world of the rabbis, women are to be. Her emotional outburst and physical spillage of such a valuable commodity reveals the ways in which she — and not Ulla—destabilizes the order and is firmly other.

Ulla seems to support R. Nahman's plan regarding the additional cup, albeit using a stronger, more disparaging tone. Unlike R. Nahman, who speaks to Ulla and not to Yalta, Ulla speaks directly to Yalta. In so doing, he infantilizes her and provokes her to lash out at him, not with words of Torah, but with insulting words:

He [Ulla] sent ${ }^{40}$ it to her [saying the following]: "All the wine [from] this barrel can be [counted as] the wine of blessing."

39 See Judith P. Goetz and Linda Grant, "Conceptual Approaches to Studying Gender in Education," Anthropology and Education Quarterly 19 (1988):182-196, as discussed in Ben-Yosef, "Literacy and Power," 59.

40 The word "sent" from the Hebrew root, שדר, is somewhat unclear as it makes this interchange between Ulla and Yalta seem as though they are not speaking directly to one another. However, a look at b. Qidd. 7oa shows that the word "sending" can mean talking to a woman. Qidd. 7oa is as follows: "[R. Nahman said]: Let the Master 'send' [greetings] of peace to Yalta." Read along with b. Ber. $5 \mathrm{lb}$ and noting that Yalta responds to Ulla, suggests that Ulla must have said something to her that provoked her words of insult.

41 Note that while the manuscript traditions indicate that this story (b. Ber. 51ab) is relatively stable, both the Munich manuscript (97) and the Paris manuscript (671) do not include R. Nahman's second request that Ulla send Yalta another cup. Instead, following Yalta's decision to break 400 barrels of wine, Ulla retorts, "All the wine [from] this barrel can be [counted as] the wine of blessing." Then Yalta responds with words of insult. Without the second request of R. Nahman, the harshness of Ulla's retort is intensified. Yalta breaks the barrels, at which point Ulla implies that she has destroyed all blessing. 
She sent him [a response]: "From itinerant [peddlers come idle] words and from old rags [come] lice."

As Ulla tries to placate Yalta, he invents a way of deeming the second cup of wine to be considered "a cup of blessing" by claiming that the entire barrel from which the wine was originally taken was blessed. But, are there any barrels left? Has Yalta destroyed them all? Are Ulla and R. Nahman trying to say- "Ha! you missed one?" Is there a pitcher of wine on the table from which the first cup of blessing was poured? Here these two rabbis emerge more as facetious men trying to convince Yalta that the cup can still be passed to her, than as legal experts with a viable solution. In the end, Yalta is not fooled. She is familiar with the ritual and knows she is being duped. Even if the barrel (or the pitcher from which wine was drawn for the first cup) is still intact, they cannot make up for Ulla's refusal to include her initially with a second cup. Voicing her despair this time around, Yalta transposes a folk-saying found in the book of Ben Sira 42:13 that connects the notion of wickedness coming from women with insects coming from cloth. ${ }^{42}$ Instead, as Yalta utters, wickedness comes not from women, but from itinerant rabbis such as Ulla, who try to exercise authority over rabbis, like R. Nahman, not to mention those who dismiss women when engaged in ritual tied to eating. Yalta's anger intensifies.

There is no end to the story. The concluding remark is made by Yalta, which silences Ulla and R. Nahman. Any evaluation as to whether she is right or wrong is absent. And finally, no one is reproved. ${ }^{43}$ Talmudic literature is replete with material that discusses punishments for individuals who lodge insults, including rabbis. Punishments, such as 30-day bans (nidui) or harsher excommunications (herem), ensure a stable social order where social interactions operate according to a set of enforceable rules. So now the question that arises is why did the redactors of the Talmud preserve this story? ${ }^{44}$ Why include a story that

42 See Sir 42:13, "From a garment comes moths and from a woman wickedness." Also see Ilan, Mine and Yours Are Hers, 125 and note 66. Although it is not clear whether Yalta had any familiarity with the book of Ben Sira, the rabbis were certainly aware of it. See b. Sanh. 1oob where the lines found prior to this verse are quoted.

43 See b. Mo'ed Qat. 14b-16b regarding punishments for lodging insults at someone else. See Jason Sion Mokhtarian, "Excommunication in Jewish Babylonia: Comparing Bavli Moed Qatan 14b-17b and the Aramaic Bowl Spells in a Sassanian Context," Harvard Theological Review 108, no. 4 (2015): 553-554.

44 Others ask this question about sources mentioning women that appear to subvert mainstream rabbinic thinking, including Gail Labovitz who queries: What does the inclusion 
underscores the challenges of rabbi-rabbi collegiality; accentuates the dangers of asserting rabbinic authority in developing interpersonal relations and exposes egocentrism; competition and exclusion in the acquisition and dissemination of Torah knowledge? Why intimate that what binds people together in rabbinic culture, meaning Torah and ritual, can drive a wedge between them and make companionship difficult? Ulla also does more than dismiss Yalta; he excludes her from blessing.

Following in the footsteps of Mieke Bal's feminist readings of biblical texts, it is important to note that rabbis establish and sustain a working culture that is patriarchal. However, they also indicate that companionship rooted in dominance and exclusion is not "unproblematically established." ${ }^{35}$ When Ulla, R. Nahman and Yalta meet for the same meal, the patriarchy is visible, but so are its consequences. ${ }^{46}$ Feminist scholars might be drawn to Yalta as the protagonist who stands for all that does not fit in rabbinic culture. Ulla, after all, does not think she, or any woman for that matter, deserves to be counted, even in birthing children, highlighting a male-centered view of continuity. ${ }^{47} \mathrm{He}$ denies Yalta's personhood making her the quintessential outsider in the name of power and authority. Women are mere receptacles for the seed of men, that is, ironically, in the wake of Ulla's decision to appear as a mere vessel of rabbinic teaching, quoting his predecessor, rather than as an inventive contributor. But, Yalta's presence also brings out the egocentrism, the jealousy, the insecurity, and the disrespect that can exist between male rabbis who, in this case, are dis-

of stories into rabbinic literature, like this one about Yalta, imply about the rabbis and rabbinic culture? See "Rabbis and 'Guerrilla Girls': A Bavli Motif of the Female (Counter) Voice in the Rabbinic Legal System," Women in Judaism: A Multidisciplinary E-Journal 10, no. 2 (2013), https://wjudaism.library.utoronto.ca/index.php/wjudaism/article/view/ 20906/17081.

45 Mieke Bal, Lethal Love (Bloomington: Indiana University Press, 1987), 3; and also see Hasan-Rokem, Tales of the Neighborhood, 61.

46 Bal, Lethal Love, 5 .

47 See past scholarship on Yalta, including Rachel Adler, Engendering Judaism: An Inclusive Theology and Ethics (Philadelphia:Jewish Publication Society, 1998), 57; Charlotte Elisheva Fonrobert, Menstrual Purity: Rabbinic and Christian Reconstructions of Biblical Gender (Stanford: Stanford University Press, 2000), 120; and Gail Labovitz who builds upon their work in "Rabbis and 'Guerrilla Girls': A Bavli Motif of the Female (Counter) Voice in the Rabbinic Legal System." Indeed, Labovitz identifies other stories in the Bavli not only of female participation and agency, but also of barriers to female entry into legal settings. See Admiel Kosman, "A Cup of Affront and Anger: Yaltha as an Early Feminist in the Talmud," Journal of Textual Reasoning, https://jtr.shanti.virginia.edu/volume-6-number-2/a -cup-of-affront-and-anger-yaltha-as-an-early-feminist-in-the-talmud/. And see Ilan, Mine and Yours Are Hers, 121-130. 
agreeing about who receives God's blessing and about how they receive it (via the original cup or the second one). Their failure to model an effective interpersonal rabbi-rabbi relationship, accentuated by the fact that the story does not end with any final words exchanged between them, means that the rabbis, in including this story, are willing to expose the fault lines in the patriarchal homosocial society they operate within and wish to sustain. The rabbis admit that patriarchies falter, a point that is often overlooked. While at times it is a woman who is disempowered, at others, it is a rabbi who disempowers another of equal status in the name of Torah, a rabbi who is supposed to be his haver. Furthermore, if the pattern of learning in rabbinic culture is entirely social, such that learning with and through another is highly valued and generative, occurring not only in batei midrash, but also at one's table, then relationships become the fodder upon which rabbinic society is built and sustained. Unfortunately, as this story reveals, human personalities can threaten the formation of needed interpersonal relationships. Ego impedes relationships. The need to be in control evokes anger in those who are excluded. ${ }^{48}$ Disrespect drives people apart. Power that is tied to knowledge and/or to gender, can prevent or destroy rabbi-rabbi relationships (Ulla-R. Nahman), male-female relationships (Ulla and Yalta/R. Nahman and Yalta), and husband-wife relationships (if R. Nahmman and Yalta are husband and wife). Interpersonal relationships, formed within a patriarchal structure and governed by how much Torah one knows, run the danger of promoting worlds that lack dynamism and make limited room for even those who belong to the same social structure. The rabbis admit through the interchange between R. Nahman, Ulla, and Yalta in Ber. $5^{1 \mathrm{~b}}$ that patriarchal structures can frustrate relationships, even those among equals, inasmuch as they construct patterns of belonging that inspire connection. ${ }^{49}$

48 Stein, "A Maidservant and Her Master's Voice," 379 and 384, suggests that there cannot be any relationship when you fall in love with yourself, like the Greek Narcissus who sees his reflection in a pool of water.

49 As Judith Hauptman argues, it is possible that the rabbis were not entirely comfortable with their patriarchal privilege and, therefore, sought ways to ameliorate the status of women. See Rereading the Rabbis: A Woman's Voice (Boulder: Westview Press, 1998), 4. Moreover, as Hauptman points out, not all Talmudic women abided by disempowering structures (Yalta) and not all men wanted to silence them (R. Nahman). In her article, "A New View of Women and Torah Study in the Talmudic Period," 249-292, https://www .biu.ac.il/JS/JSIJ/9-2010/Hauptman.pdf, Hauptman is clear to point out that men relied on women in many categories of law in order to properly observe it. Women voice their knowledge. 
This rabbinic story is about characters who, on the one hand, appear to be members of the same communal structure-who sit at tables together much like friends do - but, at the same time, stand in tense, ambivalent relationships to one another. ${ }^{50}$ They are embedded in an organizational communal structure related to Torah and halakhah that dictates the boundaries of their relationships, that is, with how male rabbis relate to other male rabbis and with how male rabbis relate to women. But, what we observe is both the potential and the loss. Ulla is connected to R. Nahman by virtue of them both being rabbis, even though they live miles apart. Potentially, they can bridge two centers of Torah learning. And yet, the competition between Babylonian Jewry and that of the Land of Israel, as represented in the R. Nahman and Ulla disagreement over the ritual of the "cup of blessing," reveals the obstacles that can work against companionship and strong interpersonal relationships needed for learning Torah. In the process, some, like Yalta, will find themselves completely sidelined and, therefore, suffer a greater sense of loss than others.

And so-looking at rabbinic texts brings to light the question as to whether exclusivity and exceptionalism, empowerment and disempowerment—all of which are characteristics of patriarchies-generate strong social fabrics. Indeed, when Robert Frost asked himself this question- "Why do [fences] make good neighbors,"- he responded that before he would build a wall he would ask to know, "what I was walling in or walling out, and to whom I was likely to give offense." ${ }^{51}$ However, despite the recognizable downsides of a patriarchal social fabric, which the rabbis in b. Ber. $5 \mathrm{lb}$ unabashedly critique, the patriarchy was continuously reinvoked and protected. More equitable social models never arose. The story of Ulla, R. Nahman, and Yalta indicates that some rabbis were struggling with the model they had created, but not enough to propose another social structure. After all, Torah learning happened; intellectual productivity ensued for generations. As such, the message that emerges from this story is to look harder at the issues that constrain us today and determine the extent to which the nature of relationships is informed by past social structures. Indeed, the goal is to rejoice in what has changed, like the admission 34 years ago of women to rabbinical school because of rabbis and scholars like Rabbi Joel Roth who spoke out relying on halakhah to enable this to happen. But we also need to assess what remains to be changed to avoid the type of behavior that results in irreparable damage or in stories that are told and retold offering no good endings. ${ }^{52}$

\footnotetext{
$50 \quad$ Bal, Lethal Love, $4-5$.

51 Robert Frost, The Poetry of Robert Frost, ed. Edward Connery Lathem (1916, etc.).

52 Mary Beard, Women and Power: A Manifesto (New York: Liveright Publishing Corporation, 2017), 97 .
} 


\section{Bibliography}

Adler, Rachel. Engendering Judaism: An Inclusive Theology and Ethics. Philadelphia: Jewish Publication Society, 1998.

Allan, Graham. Friendship:Developing a Sociological Perspective. Boulder, co:Westview, 1989.

Arnot, Madeleine. "Male Hegemony, Social Class, and Women's Education." Journal of Education 164, no. 1 (1982): 64-89.

Bal, Mieke. Lethal Love. Bloomington: Indiana University Press, 1987.

Beard, Mary. Women and Power: A Manifesto. New York: Liveright, 2017.

Ben-Yosef, Elite. "Literacy and Power: The Shiyour as a Site of Subordination and Empowerment for Chabad Women." Journal of Feminist Studies in Religion 27, no. 1 (2011): 53-74.

Berger, Moshe. "Towards the Development of Jewish Pedagogy: Rav Hiya's Vision of Torah Education." In Judaism and Education: Essays in Honor of Walter I. Ackerman. Edited by Haim Marantz, 109-120. Beer-sheva: Ben Gurion University of the Negev Press, 1998.

Boyarin, Daniel. Carnal Israel. Berkeley: University of California Press, 1993.

Boyarin, Daniel. "Rabbinic Resistance to Male Domination: A Case Study in Talmudic Cultural Poetics." In Interpreting Judaism in a Postmodern Age. Edited by Steven Kepnes, 118-141. New York: New York University Press, 1996.

Boyarin, Daniel. "Reading Androcentrism against the Grain: Women, Sex, and TorahStudy." Poetics Today 12, no. 1 (1991): 29-53.

Boyarin, Daniel. Unheroic Conduct: The Rise of Heterosexuality and the Invention of the Jewish Man. Berkeley: University of California Press, 1997.

Fitzgerald, W. Slavery in the Literary Imagination. Cambridge: Cambridge University Press, 2000.

Fonrobert, Charlotte. "Feminist Interpretation of Rabbinic Literature: Two Views." Nashim: A Journal of Jewish Women's Studies and Gender Issues 4 (2001): 7-14.

Fonrobert, Charlotte. "Gender Politics in the Rabbinic Neighborhood: Tractate Eruvin." In A Feminist Commentary on the Babylonian Talmud: Introduction and Studies. Edited by T. Ilan et al., 43-59 Tübingen: Mohr Siebeck, 2007.

Fonrobert, Charlotte E. Menstrual Purity: Rabbinic and Christian Reconstructions of Biblical Gender. Stanford: Stanford University Press, 2000.

Frost, Robert. The Poetry of Robert Frost. Edited by Edward Connery Lathem. (1916, etc.).

Goetz, Judith P., and Linda Grant. "Conceptual Approaches to Studying Gender in Education." Anthropology and Education Quarterly 19 (1988): 182-196.

Hasan-Rokem, Galit. Tales of the Neighborhood:Jewish Narrative Dialogues in Late Antiquity. Berkeley: University of California Press, 2003. 
Hauptman, Judith. "From the Kitchen to the Dining Room: Women and Ritual Activities in Tractate Pesahim." In A Feminist Commentary on the Babylonian Talmud:Introduction and Studies. Edited by T. Ilan et al., 109-126. Tübingen: Mohr Siebeck, 2007.

Hauptman, Judith. "Hadavar masur lenashim: Nashim betekasei daat beitim." Sidra (5770): 83-111.

Hauptman, Judith. "A New View of Women and Torah Study in the Talmudic Period." JSIJ 9 (2O10): 249-292. Online: https://www.biu.ac.il/JS/JSIJ/9-2010/Hauptman.pdf.

Hauptman, Judith. Rereading the Rabbis: A Woman's Voice. Boulder, co: Westview, 1998. Hausfather, Samuel J. "Vygotsky and Schooling: Creating a Social Context for Learning." Action in Teacher Education 18 (1996): 1-4.

Hegel, George Wilhelm. Phenomenology of the Mind. Translated by J.B. Baillie. London: Sonnenschein, 1910.

Hezser, Catherine. "Rabbis and Other Friends." In The Talmud Yerushalmi and GraecoRoman Culture. Edited by P. Schäfer and C. Hezser, 2:189-254. Tübingen: Mohr Siebeck, 2000.

Hezser, Catherine. The Social Structure of the Rabbinic Movement in Roman Palestine. Tübingen: Mohr Siebeck, 1997 .

Holzer, Elie. Attuned Learning: Rabbinic Texts on Habits of the Heart in Learning Interactions. Boston: Academic Studies, 2016.

Holzer, Elie, and Orit Kent. A Philosophy of Havruta: Understanding and Teaching the Art of Text Study in Pairs. Boston: Academic Studies, 2014.

Ilan, Tal. Mine and Yours Are Hers: Retrieving Women's History from Rabbinic Literature. Leiden: Brill, 1997.

Kanarek, Jane, and Marjorie Lehman. "Making a Case for Rabbinic Pedagogy." In The International Handbook of Jewish Education. Edited by L. Grant and A. Pomson, 581596. New York: Springer, 2011.

Kosman, Admiel. "A Cup of Affront and Anger: Yaltha as an Early Feminist in the Talmud." Journal of Textual Reasoning 6, no. 2. Online: https://jtr.shanti.virginia.edu/ volume-6-number-2/a-cup-of-affront-and-anger-yaltha-as-an-early-feminist-in-the -talmud/.

Kress, Jeff, and Marjorie Lehman. "The Babylonian Talmud in Cognitive Perspective: Reflections on the Nature of the Bavli and Its Pedagogical Implications." Journal of Jewish Education 69, no. 2 (2003): 58-78.

Labovitz, Gail. "Rabbis and 'Guerrilla Girls': A Bavli Motif of the Female (Counter) Voice in the Rabbinic Legal System." Women in Judaism: A Multidisciplinary E-Journal 10, no. 2 (2013). Online: https://wjudaism.library.utoronto.ca/index.php/wjudaism/ article/view/209o6/17081.

Lehman, Marjorie. "Reading Beruriah through the Lens of Isaac Bashevis Singer's Yentl." Nashim: A Journal of Jewish Women's Studies and Gender Issues 31, no. 1 (2017): 123145 . 
Levisohn, J.A., and S.P. Fendrick, eds. Turn It and Turn It Again: Studies in the Teaching and Learning of Classical Jewish Texts. Boston: Academic Studies, 2013.

Mokhtarian, Jason Sion. "Excommunication in Jewish Babylonia: Comparing Bavli Moed Qatan 14b-17b and the Aramaic Bowl Spells in a Sassanian Context." Harvard Theological Review 108, no. 4 (2015): 552-578.

Rubenstein, Jeffrey. "Social and Institutional Settings of Rabbinic Literature." In The Cambridge Companion to Talmud and Rabbinic Literature. Edited by Charlotte Elisheva Fonrobert and Martin S. Jaffee, 59-6o. Cambridge: Cambridge University Press, 2007.

Satlow, Michael. "Fictional Women: A Study in Stereotypes." In The Talmud Yerushalmi and Greco-Roman Culture. Edited by P. Schafer, 3:225-243. Tübingen: Mohr Siebeck, 2002.

Sawicki, Jana. Disciplining Foucault: Feminism, Power, and the Body (Thinking Gender). New York: Routledge, 1991.

Schofer, Jonathan Wyn. The Making of a Sage: A Study in Rabbinic Ethics. Madison: University of Wisconsin Press, 2005 .

Stein, Dina. "A Maidservant and Her Master's Voice: Discourse, Identity, and Eros in Rabbinic Texts." Journal of the History of Sexuality 10, nos. 3-4 (2001): 375-397.

Wertsch, James A. Vygotsky and the Social Formation of the Mind. Cambridge: Harvard University Press, 1985. 